\title{
A new species of Hoplomyzon (Siluriformes: Aspredinidae) from Maracaibo Basin, Venezuela: osteological description using high-resolution computed microtomography of a miniature species
}

\author{
Tiago P. Carvalho ${ }^{1,2}$, Roberto E. Reis ${ }^{3}$ and John P. Friel ${ }^{4}$
}

A new miniature species of banjo catfish of the genus Hoplomyzon is described from the Lake Maracaibo Basin in Venezuela. The new species is distinguished from all its congeners by the straight anterior margin of the mesethmoid ( $v s$. a medial notch); a smooth and straight ventral surface of the premaxilla ( $v s$. presence of bony knobs on the ventral surface of premaxilla); absence of teeth on dentary ( $v s$. teeth present on dentary); configuration of ventral vertebral processes anterior to anal fin, which are composed of single processes anterior to anal-fin pterygiophore (vs. paired process); presence of several filamentous barbel-like structures on the ventral surface of head of adults (vs. small papillous structures in the ventral surface of head of adults); and 8 anal-fin rays (vs. 6 or 7). An extensive osteological description is made of the holotype using high-resolution x-ray computed microtomography (HRXCT).

Keywords: Endemism, Ernstichthys intonsus, Miniaturization, Synapomorphy, Taxonomy.

Se describe una nueva especie miniatura de pez banjo perteneciente al género Hoplomyzon, proveniente de tributarios del Lago Maracaibo en Venezuela. La nueva especie se diferencia de sus congéneres por presentar el margen anterior del mesetmoide recto ( $v s$. con una hendidura central); superficie ventral de la premaxila lisa y recta ( $v s$. superficie ventral de la premaxila con protuberancias óseas); ausencia de dientes en el dentario ( $v s$. dientes presentes); configuración de los procesos anteriores ventrales de la aleta anal, los que están compuestos de procesos simples anteriores al pterigióforo de la aleta anal (vs. procesos dobles); presencia de varias estructuras en forma de barbillas en la superficie ventral de la cabeza ( $v s$. pequeñas estructuras en forma de papilas en la superficie ventral de la cabeza); y 8 radios en la aleta anal ( $v s .6$ o 7). Una extensiva descripción osteológica del holotipo fue realizada utilizando microtomografía computarizada de rayos X de alta resolución (HRCXCT).

Palabras Clave: Endemismo, Ernstichthys intonsus, Miniaturización, Sinapomorfia, Taxonomía.

\section{Introduction}

Hoplomyzon Myers, 1942 is a member of the aspredinid tribe Hoplomyzontini, a small and peculiar group of armored banjo catfishes of small body sizes and distinctive, specialized morphologies (Stewart, 1985). Hoplomyzontins, composed of genera Hoplomyzon, Dupouyichthys Schultz, 1944, Ernstichthys, Fernández-Yépez, 1953 and Micromyzon Friel \& Lundberg, 1996, are generally collected in the deep channels of medium to large sized rivers and as a consequence they are rare in museum collections
(Stewart, 1985; Taphorn, Marrero, 1990; Friel, Lundberg, 1996; Carvalho et al., 2016; Carvalho et al., in press). The distribution of Hoplomyzon species is restricted to piedmont tributaries of Lake Maracaibo, plus the Orinoco and Amazon basins (Friel, 2003). As currently recognized, Hoplomyzon contains only three valid species: Hoplomyzon atrizona Myers, 1942, type species of the genus, known from Lake Maracaibo tributaries; H. papillatus Stewart, 1985 from the Amazon and Orinoco river basins; and $H$. sexpapilostoma Taphorn \& Marrero, 1990 endemic to the Orinoco River basin (Friel, 1994, 2003).

\footnotetext{
${ }^{1}$ Laboratório de Ictiologia, Departamento de Zoologia, Universidade Federal do Rio Grande do Sul. Av. Bento Gonçalves, 9500, 91501970 Porto Alegre, RS, Brazil. carvalho.ictio@gmail.com (corresponding author)

${ }^{2}$ Department of Ichthyology, The Academy of Natural Sciences of Drexel University, 1900 Benjamin Franklin Parkway, 19103-1195 Philadelphia, PA, USA.

${ }^{3}$ Laboratório de Sistemática de Vertebrados, Faculdade de Biociências, PUCRS. Caixa Postal 1429, 90619-900 Porto Alegre, RS, Brazil. reis@pucrs.br

${ }^{4}$ Alabama Museum of Natural History, The University of Alabama, Box 870340, 35487-0340 Tuscaloosa, AL, USA. jpfriel@ua.edu
} 
Stewart (1985), in a review of Hoplomyzontini, based on the relatively small number of specimens available at that time, diagnosed the genus Hoplomyzon by possessing four or five stout, fleshy papillae on upper lip, 11 pre-analfin plates (corresponding two anterior unpaired elements, four sets of paired elements, and the anal-fin pterygiophore exposed ventrally), short cleithral and scapulocoracoid processes (10.1-12.5 and 8.9-10.8\% SL, respectively), and short pectoral-fin spine (less than 25\% SL). Friel (1994), in a phylogenetic analysis of the family Aspredinidae, diagnosed Hoplomyzon from other aspredinid genera by having two bony knobs on ventral surface of premaxilla, superficially covered by fleshy papillae, dorsal and ventral plates not overlapping adjacent ones, two or three sets of paired pre-anal-fin plates, a maxillary barbel adnate to head by membrane, and a short pectoral-fin spine (less than $25 \%$ SL). Of these characters, only the presence of premaxillary knobs on ventral surface of the premaxilla was recovered as an unambiguous synapomorphy (Friel, 1994), other diagnostic features ambiguous within Hoplomyzontini. Contrastingly, the tribe Hoplomyzontini is perhaps the most well supported group of Aspredinidae with 27 unambiguous morphological synapomorphies (see Friel, 1994: 91) reflecting its specialized and unique morphology.

The Maracaibo Basin has 127 species of freshwater fishes and more than half of those are endemic (Albert et al., 2011). Here we describe a new species of Hoplomyzon endemic to the Maracaibo Basin, and present osteological descriptions of this miniature fish based on high-resolution $\mathrm{x}$-ray computed microtomography (HRXCT).

\section{Material and Methods}

Measurements were taken point to point with digital calipers. Relative measurements are expressed as percent of the standard length (SL), except subunits of head, expressed as percent of the head length (HL). The measurements follow those proposed by Friel (1995) and Cardoso (2010), except for cleithral process length, which was taken from the anterior margin of the cleithrum along its lateral portion to the posterior tip of the cleithral process. Vertebral counts include all preural vertebrae, including the five vertebrae modified into the Weberian Apparatus, plus the PU1+U1 and $\mathrm{U} 2$ elements on the caudal skeleton counted as a single element according to Lundberg, Baskin, (1969) and de Pinna, $\mathrm{Ng}$ (2004). Comparative cleared and stained specimens (cs) were prepared according to the method described by Taylor, Van Dyke (1985). Osteological descriptions focused on aspects and characters used in previous phylogenetic studies of the family Aspredinidae (Friel, 1994; de Pinna, 1996; Cardoso, 2008). Anatomical terminology generally follows the Teleost Anatomical Ontology (TAO; Dahdul et al., 2010) an integral part of the Uberon Ontology covering anatomical structures in animals (Mungall et al., 2012; http://uberon.github.io/). The dorsal and ventral vertebral processes are, respectively, dorsolateral and ventrolateral distally-flattened struts off the neural and hemal arches that form the dorsal and ventral body armor on the body surface (Taphorn, Marrero, 1990; fig. 4a; Friel, Lundberg, 1996; Carvalho et al., 2016). Institutional abbreviations follow Sabaj (2016). Photographs were taken of specimens mounted in a photo-tank following the techniques described by Sabaj Pérez (2009) with a Nikon D90 and a Nikon D7100 digital SLR.

\section{Results}

\section{Hoplomyzon cardosoi}

urn:1sid:zoobank.org:act:8331CD18-B92C-4F13-A403CB9718586E3F

\section{Figs. 1-11}

Holotype. MCNG 375, $18.5 \mathrm{~mm}$ SL, Venezuela, Zulia, Colon, Caño La Raya tributary to Río Escalante, Hacienda San Jose, approx. $08^{\circ} 50^{\prime} \mathrm{N} 71^{\circ} 45^{\prime} \mathrm{W}, 8$ Sep 1977, D. Taphorn and others.

Paratypes. MCNG 11560, 1, 15.7 mm SL, Venezuela, Zulia, Río Ariquaisa [Aricuaisa] bridge via Machiches, approx. $09^{\circ} 24^{\prime} \mathrm{N} 72^{\circ} 36^{\prime} \mathrm{W}, 14$ Mar 1981, D. Taphorn. MCNG 26955, 1, $15.1 \mathrm{~mm}$ SL, Venezuela, Zulia, Río Santa Ana, approx. $09^{\circ} 23^{\prime} \mathrm{N} 72^{\circ} 36^{\prime} \mathrm{W}, 10$ Dec 1982, F. Mago Leccia.

Diagnosis. Hoplomyzon cardosoi is distinguished from all congeners by the straight anterior margin of the mesethmoid (vs. with medial notch); a smooth and straight ventral surface of the premaxilla ( $v s$. presence of bony humps on the ventral surface of premaxilla); absence of teeth on dentary ( $v s$. teeth present on dentary); vertebrae anterior to anal-fin pterygiophore with simple ventral processes (vs. bifurcated processes); presence of several filamentous barbel-like structures on the ventral surface of head (vs. small papillous structures on the ventral surface of head); and anal-fin rays 8 (vs. 6 or 7). Additionally, Hoplomyzon cardosoi differs from remaining congeners by the following morphometric features: greater cleithral width $29.8-33.5 \%$ SL, mean 31.1 (vs. 23.5-28.7\% SL); shorter scapulocoracoid process 3.2-3.8\% SL, mean: 3.4 (vs. 5.9-6.9\% SL); longer cleithral process $14.1-20.5 \%$ SL, mean 16.4 (vs. 9.6-13.4\% SL); narrower interorbital width 26.8-27.5\% HL, mean 27.1 (vs. 28.6-36.4\% HL); lesser distance between anterior nares 14.6-20.0\% HL, mean 17.8 (vs. 25.0-28.6\% HL); and lesser distance between posterior nares $22.0-29.2 \% \mathrm{HL}$, mean: 25.4 (vs. 31.7-36.8\% HL).

Description. Morphometric data summarized in Tab. 1. Head and body depressed. Dorsal profile rising gently from snout tip to dorsal-fin origin with several small humps in between, then descending gradually to end of caudal peduncle; ventral profile straight to slightly convex from 
mouth to anus, ascending gradually from this point to end of anal fin, almost straight from this point to posterior end of caudal peduncle. Rostrum rounded in dorsal view, lacking medial mesethmoid notch. Head broad, body broadest at pectoral-fin insertion. Caudal peduncle long and slender, squarish in cross section (Figs. 1-2).

Anterior nares located dorsally about midway between snout tip and posterior nares, enclosed by fleshy tube; anterior margin of tube with small flap-like papillae. Posterior nares lacking fleshy tube, aligned with lateral margin of eye. Rostrum overhanging ventrally displaced mouth; gape small. Upper lip with pair of lateral main papillae and median unpaired one, additional small papillae displaced anterior to these ones.

Three main pairs of barbels, all simple. Maxillary barbel short, almost reaching pectoral-fin origin. Three rictal barbels within ventral portion of axillary region of maxillary barbel, longest at origin of maxillary barbel and two shorter ones posteriorly displaced about half-length of longest one.
Main mental barbels short, posterior pair laterally displaced, separated from counterpart by about twice distance of separation between anterior pair. Additional series of barbel-like filaments widespread in ventral portion of head and cleithrum, these longer on adult specimens (Figs. 1-2). Smaller specimen showing papillary structures in ventral portion of head that seem undeveloped filamentary barbels (Fig. 2b). Opercular opening small, transversely displaced relative to main body axis and not extended anteriorly, concealed by rounded membranous flap. Opercular openings separated by distance approximating length of one aperture.

Skin roughened with small rounded unculiferous tubercles. Largest tubercles on dorsal portion of head and body, smaller tubercles on ventral surface of body. Small, oblique, slit-like pore at pectoral-fin axilla. No apparent sexual dimorphism. Largest specimen (holotype, $18.5 \mathrm{~mm}$ SL) female, with several large eggs visible in ventral and lateral portions of belly (Fig. 1).

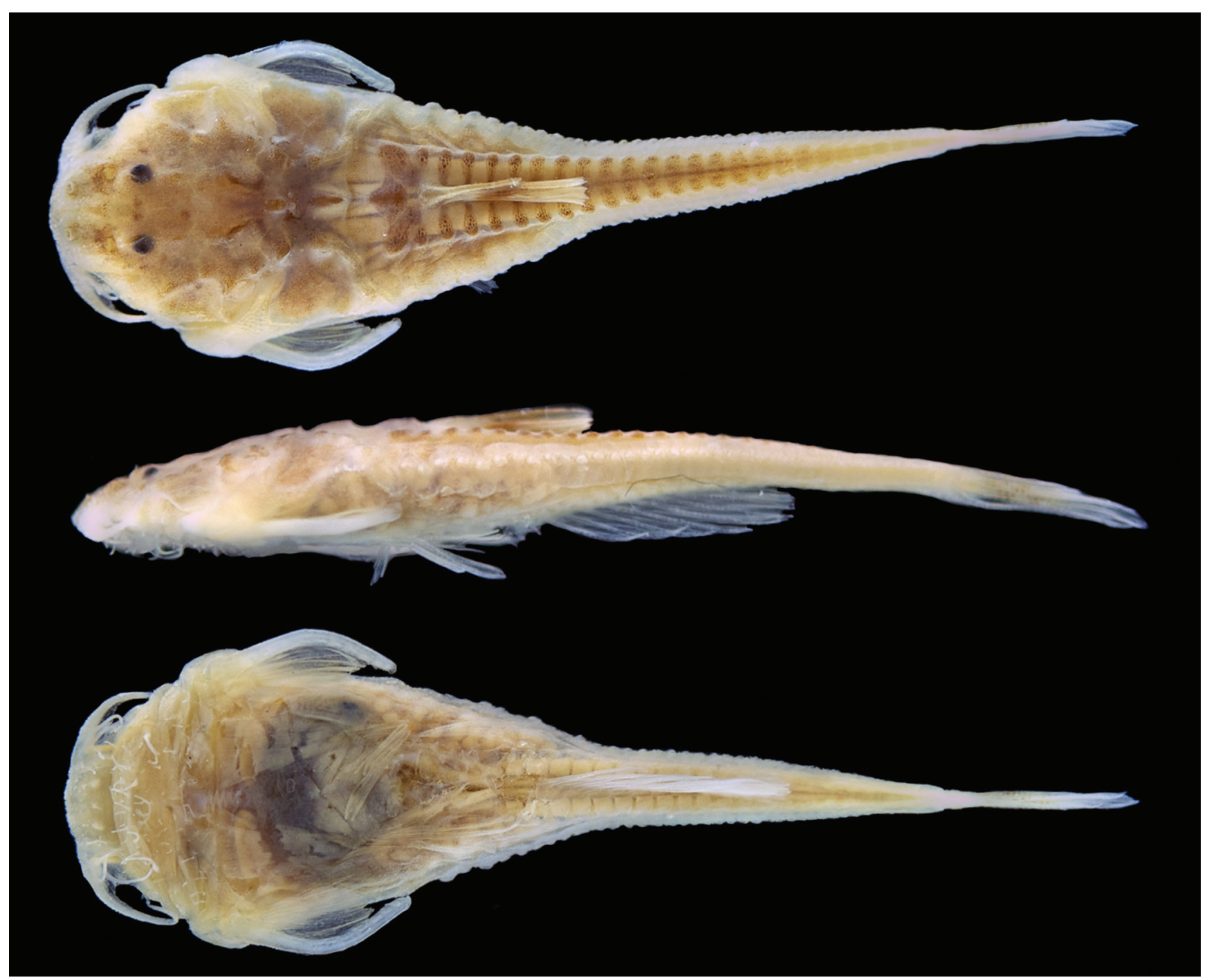

Fig. 1. Hoplomyzon cardosoi, holotype, MCNG 375, 18.5 mm SL, Caño La Raya, Zulia, Venezuela. Dorsal, left side lateral and ventral views. 
Tab. 1. Morphometric data of holotype $(\mathrm{H})$ and two paratypes $(\mathrm{P})$ of Hoplomyzon cardosoi. $\mathrm{SD}=$ standard deviation.

\begin{tabular}{|c|c|c|c|c|c|}
\hline & MCNG 375(H) & MCNG11560(P) & MCNG26955(P) & Mean & SD \\
\hline Standard length (mm) & 18.5 & 15.7 & 15.1 & 16.4 & - \\
\hline \multicolumn{6}{|c|}{ Percent of standard length } \\
\hline Head length & 25.9 & 25.4 & 27.1 & 26.2 & 0.86 \\
\hline Prepectoral length & 26.4 & 24.2 & 26.4 & 25.7 & 1.32 \\
\hline Cleithral width & 33.5 & 29.9 & 29.8 & 31.1 & 2.11 \\
\hline Maximum head depth at supraoccipital & 12.9 & 12.1 & 13.2 & 12.8 & 0.60 \\
\hline Pectoral-spine length & 17.8 & 22.2 & 23.1 & 21.1 & 2.86 \\
\hline Distance between tips of coracoid processes & 18.9 & 15.2 & 15.2 & 16.5 & 2.11 \\
\hline Posterior coracoid process length & 3.7 & 3.1 & 3.3 & 3.4 & 0.32 \\
\hline Distance between cleithral processes & 27.0 & 22.2 & 20.5 & 23.3 & 3.36 \\
\hline Posterior cleithral process length & 13.5 & 14.0 & 14.6 & 14.0 & 0.53 \\
\hline Predorsal length & 40.5 & 39.4 & 38.4 & 39.5 & 1.07 \\
\hline Depth at dorsal-spine insertion & 13.5 & 12.7 & 12.5 & 12.9 & 0.50 \\
\hline Dorsal-spine length & 18.3 & 19.1 & 19.2 & 18.9 & 0.45 \\
\hline Prepelvic length & 34.0 & 31.8 & 33.7 & 33.2 & 1.20 \\
\hline Length of $1^{\text {st }}$ pelvic-fin ray & 12.4 & - & 14.6 & 13.5 & 1.51 \\
\hline Preanal length & 51.8 & 52.2 & 50.3 & 51.5 & 1.01 \\
\hline Anal-fin base length & 20.0 & 22.9 & 22.5 & 21.8 & 1.59 \\
\hline Caudal-peduncle length & 23.7 & 28.0 & 30.4 & 27.4 & 3.38 \\
\hline Caudal-peduncle depth & 3.2 & 4.4 & 3.9 & 3.9 & 0.61 \\
\hline Caudal length & 21.0 & 22.2 & 22.5 & 22.0 & 0.77 \\
\hline \multicolumn{6}{|c|}{ Percent of head length } \\
\hline Snout length & 39.5 & 40.0 & 41.4 & 40.3 & 0.99 \\
\hline Eye diameter & 10.4 & 10.0 & 9.7 & 10.1 & 0.33 \\
\hline Interorbital width & 27.0 & 27.5 & 26.8 & 27.1 & 0.34 \\
\hline Maxillary-barbel length & 66.6 & 72.5 & 58.5 & 65.9 & 7.01 \\
\hline Distance between anterior nares & 18.7 & 20.0 & 14.6 & 17.8 & 2.81 \\
\hline Distance between posterior nares & 29.1 & 25.0 & 21.9 & 25.4 & 3.62 \\
\hline Mouth width & 37.5 & 35.0 & 34.1 & 35.5 & 1.74 \\
\hline
\end{tabular}

Neurocranium. External surfaces of skull roof bones with pitted texture and somewhat interdigitating sutures between bones. Dorsal surface of neurocranium with pronounced bony knobs at posterior dorsal surface of mesethmoid, anterior portion of frontals at orbit margin, frontal-sphenotic joint, and posterior tip of parietalsupraoccipital. Mesethmoid long and deep; its middle portion constricted in dorsal view. Anterior margin of mesethmoid straight to slightly convex in dorsal view; no medial notch and weakly projected cornua laterally (Figs. 3-4). Mesethmoid-frontal joint flat, without dorsally projecting processes. Lateral ethmoid elevating dorsoposteriorly to contact frontal, not contributing to dorsal surface of neurocranium. Lateral process of lateral ethmoid extended laterally, articulating with mesial face of autopalatine at its midlength. Frontal moderately compact (length about twice its width), deeply constricted at its middle. Lateral margin of frontal forming concave orbital margin. Frontal-parietal-supraoccipital joint somewhat interdigitating; frontal-sphenotic joint elevating from main cranial surface. Anterior cranial fontanel ovoid, short and wide (its length about half frontal length), its anterior margin surrounded by mesethmoid, remainder by frontals. Posterior cranial fontanel similarly short and wide (slightly broader than anterior cranial fontanel), diamond shaped, enclosed equally by frontal and parietalsupraoccipital (Fig. 3a). Epiphyseal bar with broad median suture (suture length slightly shorter than length of either cranial fontanel).

Parietal-supraoccipital compact, its greatest length about same as greatest width, somewhat round dorsal view with deep anterior notch Anterior arms of parietal-supraoccipital short, contacting frontal medially and sphenotic laterally. Posterior process of parietal-supraoccipital short, broad and gently rounded, direct contacting anterodorsal edge of dorsal lamina of Weberian apparatus. 


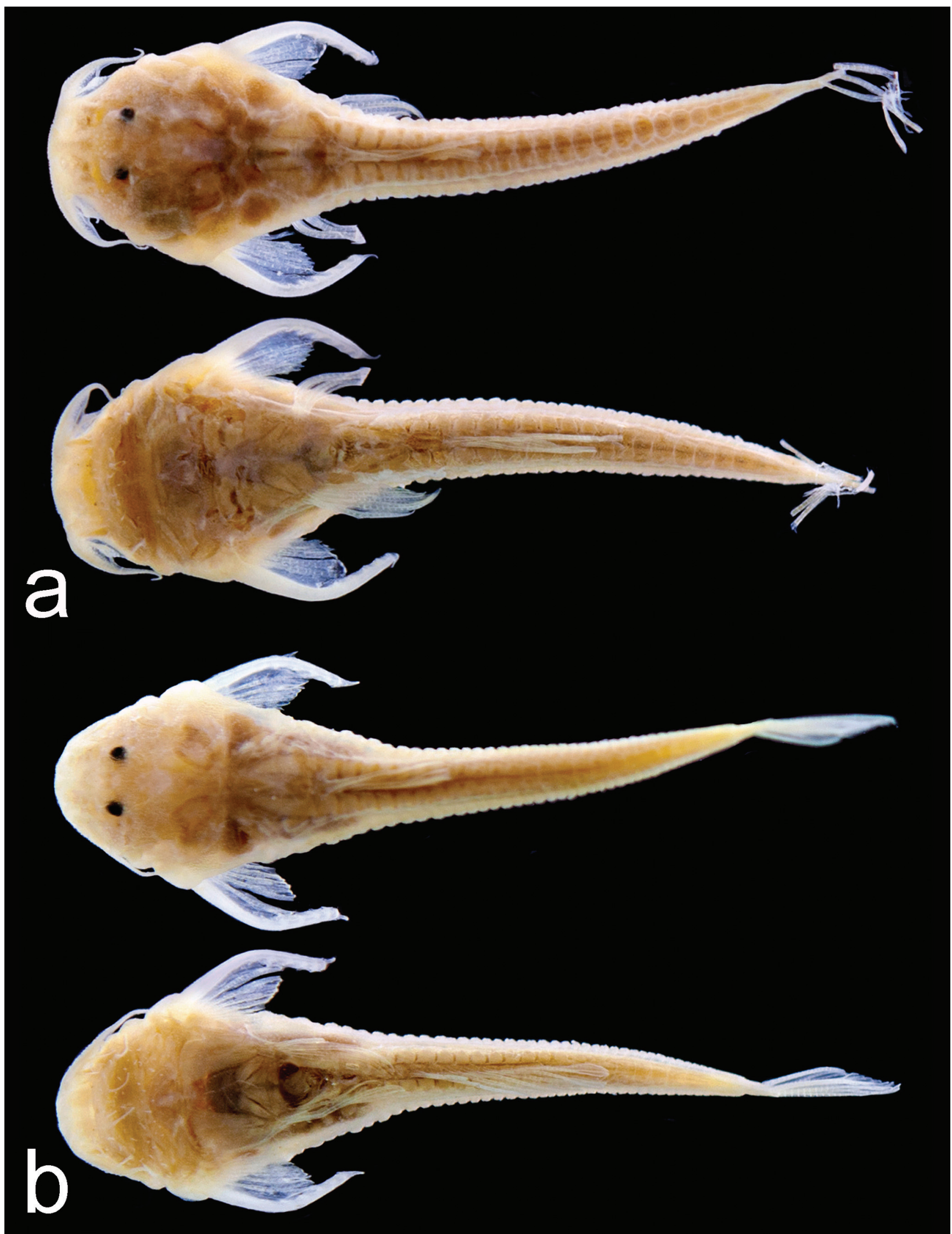

Fig. 2. Hoplomyzon cardosoi, paratypes in dorsal and ventral views. a. MCNG 26955, 15.1 mm SL. b. MCNG 11560, $15.7 \mathrm{~mm}$ SL. 


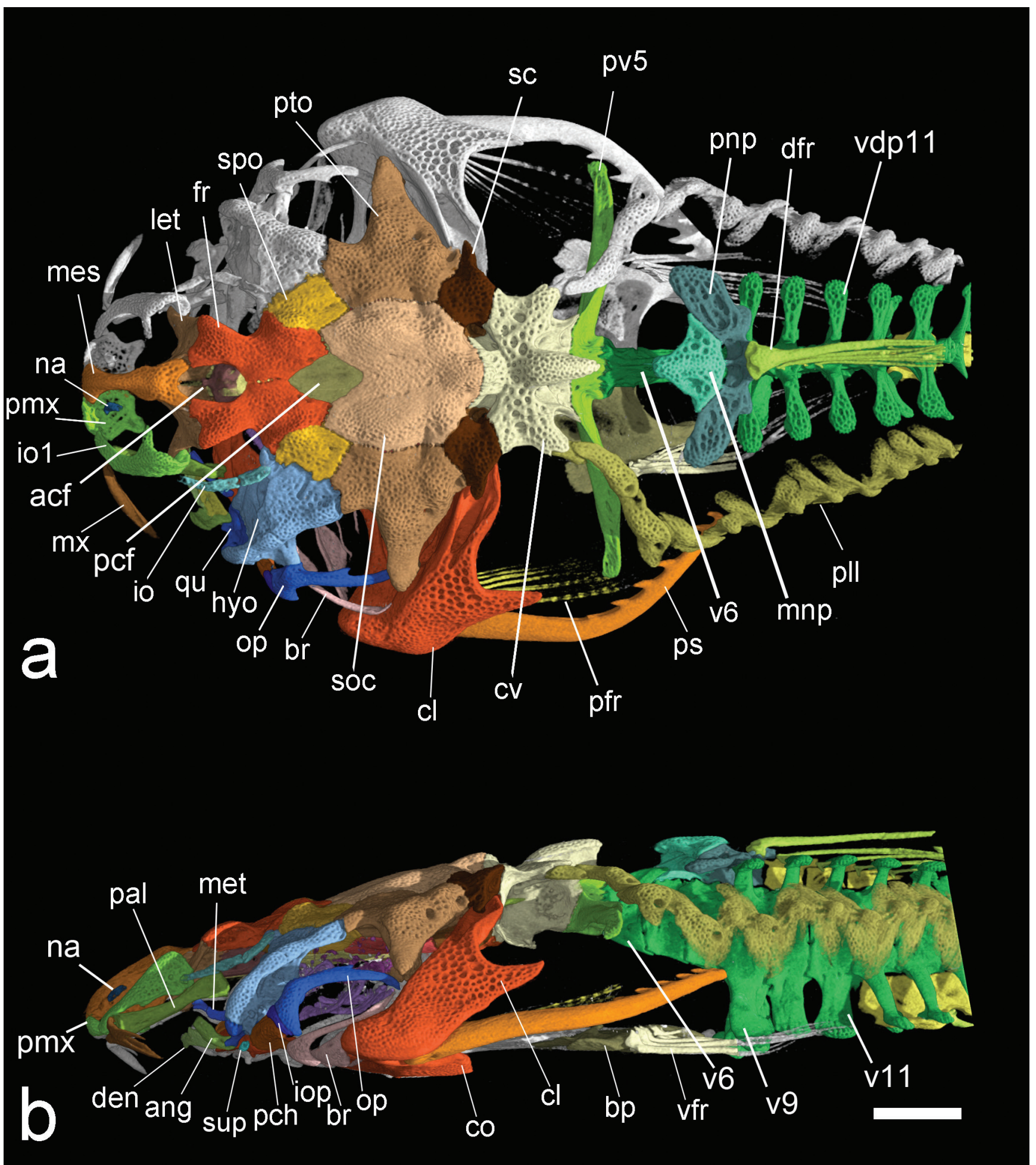

Fig. 3. HRXCT model of skull and anterior body of Hoplomyzon cardosoi, MCNG 375, holotype, $18.5 \mathrm{~mm}$ SL. a. Dorsal view. b. Lateral view of left side. acf: anterior cranial fontanel; ang: anguloarticular; bp: basipterygium; br: branchiostegal rays; cl: cleithrum; cv: complex vertebrae; den: dentary; dfr: dorsal-fin rays; fr: frontal; hyo: hyomandibula; iop: interopercle; let: lateral ethmoid; mes: mesethmoid; met: metapterygoid; mnp: middle nuchal plate; mx: maxilla; na: nasal; pal: autopalatine; pcf: posterior cranial fontanel; pch: posterior ceratohyal; pfr: pectoral fin rays; pll: posterior lateral line plates; pmx: premaxilla; ps: pectoral-fin spine; pto: pterotic; qu: quadrate; sc: postemporo-supracleithrum; soc: parietalsupraoccipital; spo: sphenotic; io1: infraorbitals; iop: interopercle; infraorbital 1; sup: subpreopercle; pv5: parapophysis of vertebra 5; v6: vertebra 6; v9: vertebra 9; v11: vertebra 11; vdp11: vertebral dorsal process of vertebra 11; vfr: pelvic-fin rays. Scale bar $=1 \mathrm{~mm}$. 


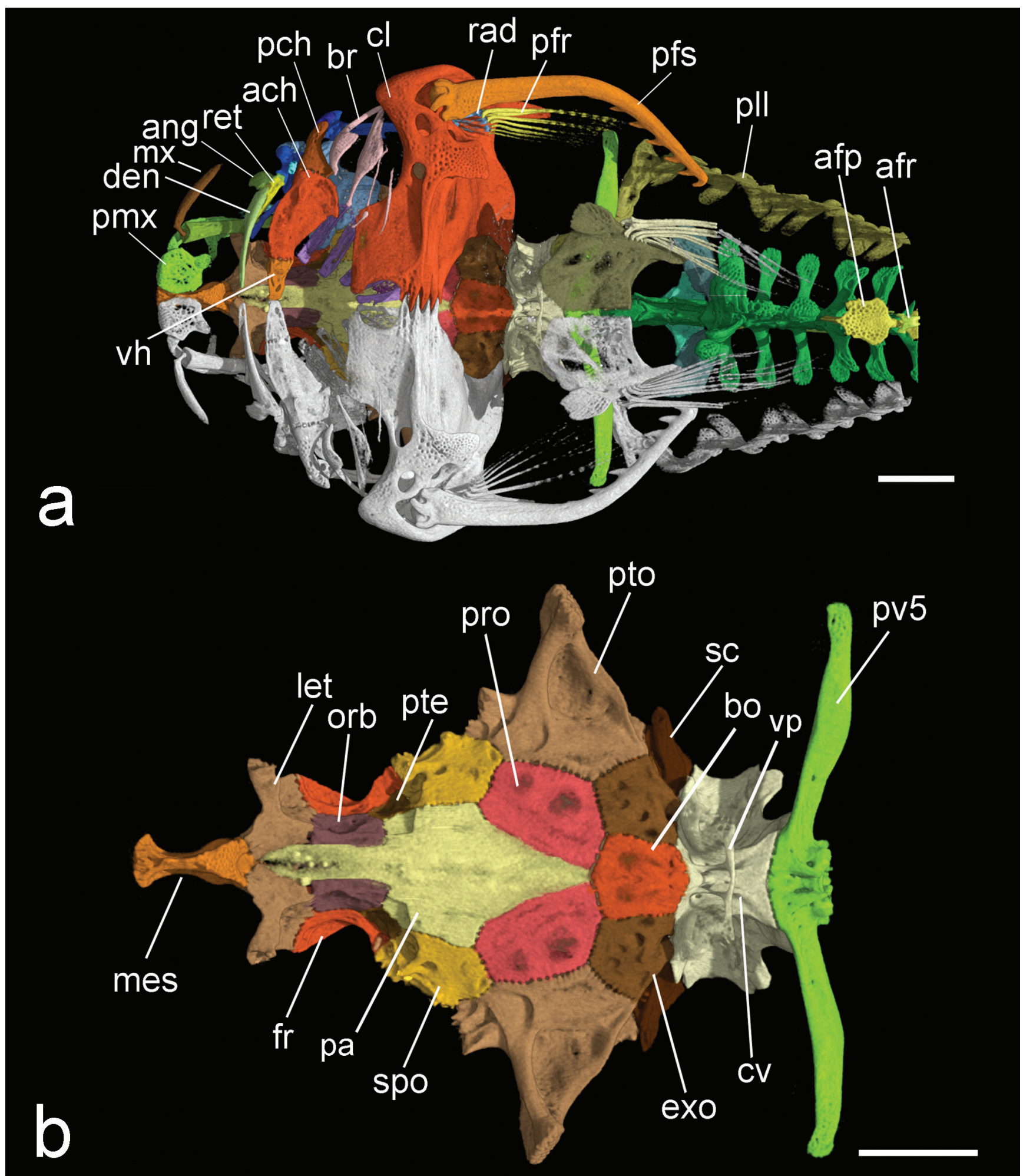

Fig. 4. HRXCT model of skull and anterior body of Hoplomyzon cardosoi, MCNG 375, holotype, 18.5 mm SL. a. Ventral view of skull and anterior body. b. Ventral view of neurocranium and first vertebrae. ang: anguloarticular; ach: anterior ceratohyal; afp: anal-fin pterygiophore; afr: anal-fin ray; bo: basioccipital; br: branchiostegal rays; cl: cleithrum; co: scapulocoracoid; cv: complex vertebrae; den: dentary; exo: exoccipital; fr: frontal; let: lateral ethmoid; mes: mesethmoid; met: metapterygoid; mx: maxilla; orb: orbitosphenoid; pa: parasphenoid; pch: posterior ceratohyal; pfr: pectoral-fin rays; pmx: premaxilla; po: preopercle; pro: prootic; ps: pectoral-fin spine; pte: pterosphenoid; pto: pterotic; pv5: parapophyses of vertebra 5; rad: pectoral-fin radial; ret: retroarticular; sc: postemporo-supracleithrum; soc: parietal-supraoccipital; spo: sphenotic; tr: tripus; vh: ventral hypohyal; vp: ventral process of complex vertebrae. Scale bars $=1 \mathrm{~mm}$. 
Sphenotic somewhat diamond shaped in dorsal view, its posterior margin contacting pterotic laterally; and extensively articulating with hyomandibula anterolaterally. Pterotic somewhat expanded anterolaterally, contacting sphenotic and hyomandibula; anterolateral margin with strongly concave margin. Pterotic wing greatly expanded laterally, tip acute. Supratemporal fossa closed; concavity at its typical position between pterotic and parietal-supraoccipital. Extrascapula absent. Postemporosupracleithrum plate-like with pitted surface, contributing to dorsal aspect of skull; contacting pterotic and parietalsupraoccipital anteriorly and parapophysis of complex vertebrae posteriorly; bordering dorsal fenestra medially; encompassed also by of the Weberian apparatus (posteriorly) and parietal-supraoccipital (anteriorly). Postemporosupracleithrum strongly sutured to surrounding bones, with laterally pointed process overlying dorsal process of cleithrum.

In ventral view of neurocranium (Fig. 4) vomer absent and parasphenoid relatively short, its anterior margin not surpassing lateral ethmoid; its posterior margin not surpassing prootic; broadest at about its middle portion (Fig. 4). Orbitosphenoid and pterosphenoid lateroventrally displaced; former four times larger than latter. Prootic somewhat hexagonal in shape, anteriorly contacting sphenotic; having two unossified regions displaced laterally; anterior foramen smaller than posterior one (likely optic and trigemino-facial nerve foramina, respectively). Basioccipital hexagonal in shape, contacting prootic and posterior tip of parasphenoid anteriorly, and Weberian compound vertebra posteriorly. Epiotic apparently absent or fused to exoccipital. Exoccipital not contributing to dorsal surface of neurocranium, and extensively contacting basioccipital.

Suspensorium and oral jaws. Premaxilla (Fig. 4a) broad and plate-like with anterior and posterior margins somewhat curved, its ventral surface rugose and not presenting bony knobs; teeth absent. Anterior margin of premaxilla with dorsally expanded process aside mesethmoid cornua; posterior margin with rounded process displaced laterally. Premaxilla displaced lateroventrally to ventral margin of mesethmoid, not contacting counterpart medially and articulating laterally with infraorbital 1 (Fig. 3a). Maxilla (Figs. 3-4) long and slender, distally bifurcate for about two-thirds its length with its ventral arm longer than dorsal. Anterior portion of maxilla with two rounded articular processes, contacting anterior face of autopalatine. Dentary slender, not contacting counterpart medially; teeth absent (Fig. 5). Anguloarticular with dorsally expanded process. Anguloarticular strongly fused with retroarticular (boundaries tentatively reconstructed in Fig. 5); both forming socket for joint with quadrate. Coronomeckelian bone absent.

Hyomandibula with well-developed anterodorsal process contacting ventral surface of contact between frontal and sphenotic. Hyomandibula extensively contacting quadrate ventrally by interdigitating suture; fused to preopercle laterally (Fig. 5). Hyomandibula with elongate posteroventrally directed process and condyle on posterior margin articulating with opercle. Preopercle strongly fused to lateral margin of hyomandibula. Preopercle with welldeveloped, laterally directed expansion, bearing canal, this exiting dorsally and passing through posterolateral portion of expanded hyomandibula before entering pterotic. Suprapreopercle absent. Quadrate subtriangular. Subpreopercle ossified as tubular canal ventral to quadrate. Entopterygoid absent or perhaps fused with anterior portion of metapterygoid. Metapterygoid elongate, constricted at midlength. Anterior margin of metapterygoid reaching lateral process of lateral ethmoid, posterior margin not contacting quadrate or hyomandibula posteriorly. Autopalatine elongate, posterior end rounded, laterally compressed and not bifurcate (Fig. 3b). Autopalatine articulating with lateral ethmoid at about its posterior third length.

Opercle (Fig. 5), boomerang shaped with posterior arm about two times longer than ventral arm. Interopercle present, wedge shaped with dorsoposterior margin firmly attached to anterior margin of ventral arm of opercle.

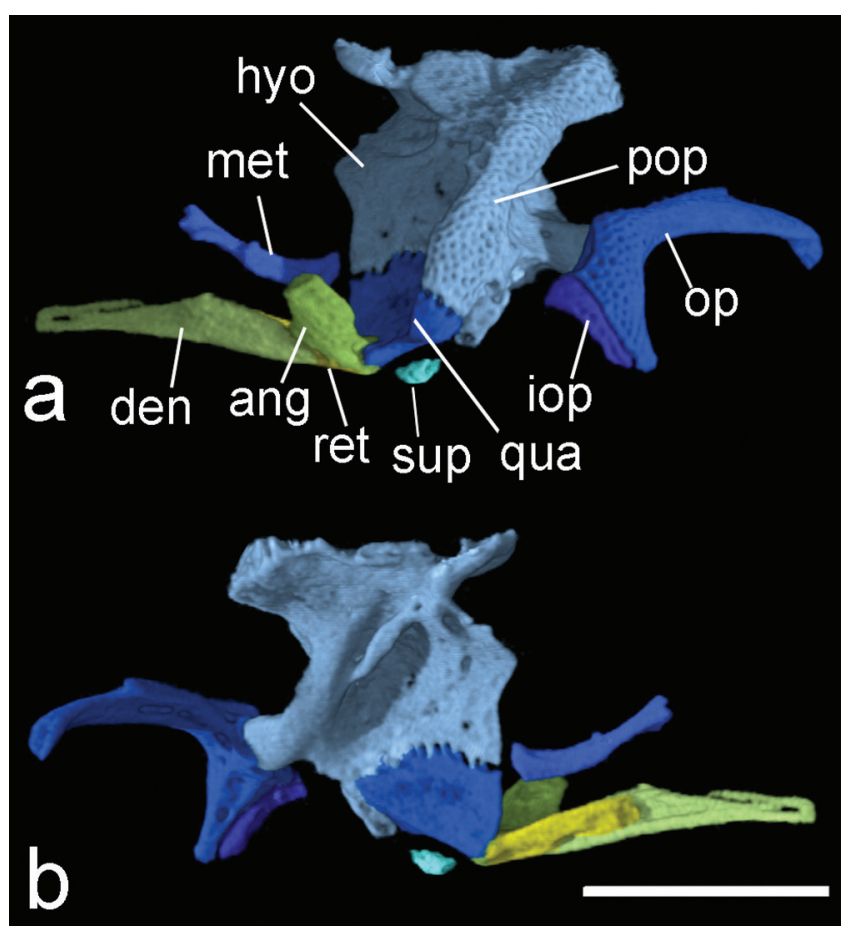

Fig. 5. HRXCT model of left side suspensorium and lower jaw of Hoplomyzon cardosoi, MCNG 375, holotype, 18.5 $\mathrm{mm}$ SL. a. Lateral view. b. Medial view. ang: anguloarticular; den: dentary; hyo: hyomandibula; iop: interopercle; met: metapterygoid; op: opercle; qu: quadrate; ret: retroarticular; sup: subpreopercle. Scale bar $=1 \mathrm{~mm}$.

Hyoid and branchial arches. Dorsal hypohyal absent. Ventral hypohyal somewhat triangular in dorsal view, contacting anterior ceratohyal laterally by interdigitating suture (Fig. 6). Anterior ceratohyal broad, its anterior margin 
not expanded into blade; greatly expanded posterolateral portion, broader than interdigitating suture with posterior ceratohyal (Fig. 6). Posterior ceratohyal somewhat triangular in shape, tapering laterally. Interhyal absent. Four branchiostegal rays; outermost (fourth) with anterior half expanded ventrally as posteriorly elongate blade; third branchiostegal expanded posteriorly from its middle to distal portion; remaining branchiostegals 3 and 4 short and slender. Parurohyal, basibranchials and hypobranchials absent. Five ceratobranchials, all bearing short gill rakers (Fig. 7); fifth ceratobranchial with one or two irregular rows of acicular teeth on dorsal surface along mesial margin. Four epibranchials, first and second slender and third and fourth broader; third epibranchial not bearing typical uncinate process (Fig. 7). Pharyngobranchials 1-2 and 4 absent. Pharyngobranchial 3 slender; positioned anterolateral to expanded circular tooth plate (Fig. 7b). Dorsal tooth plate bearing elongate acicular teeth.

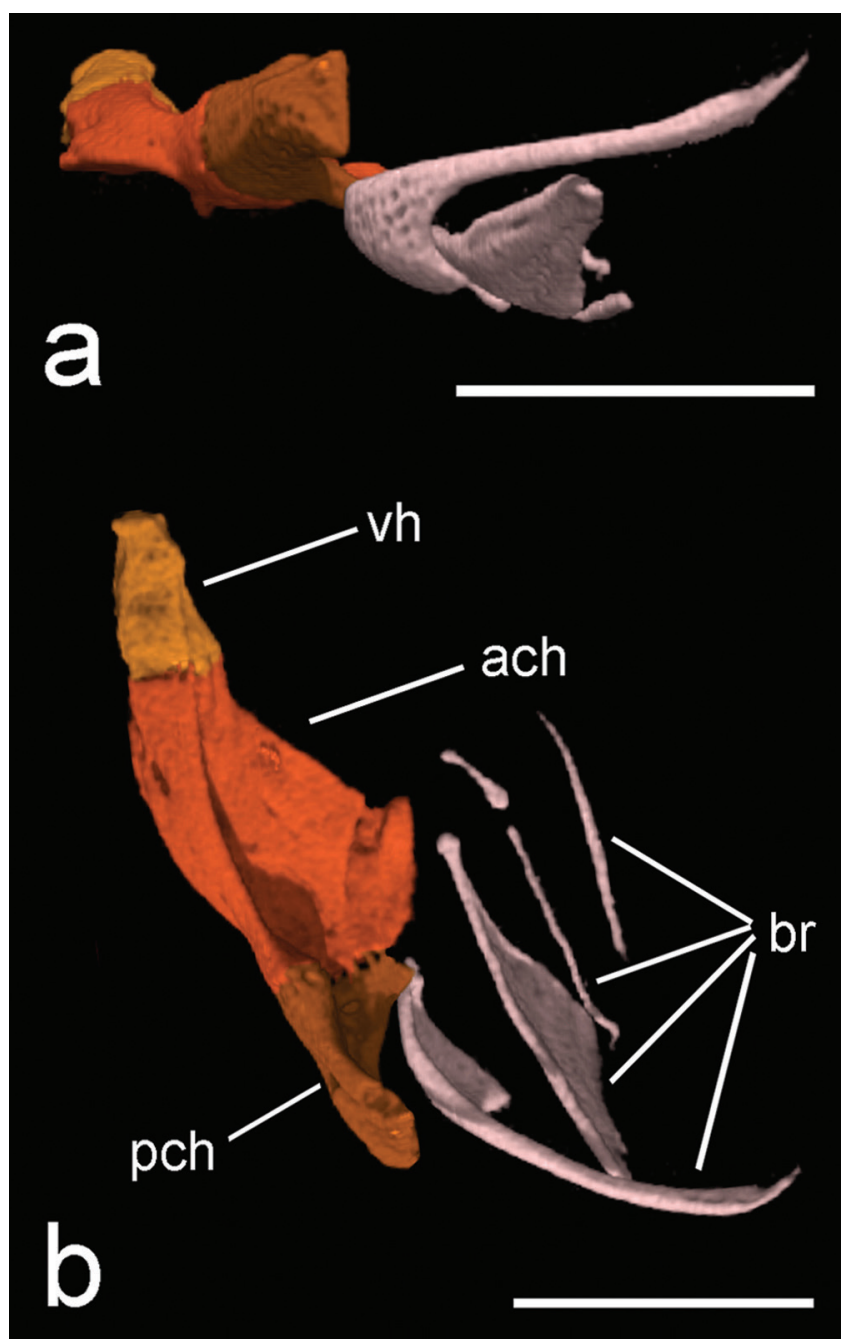

Fig. 6. HRXCT model of hyoid arch of Hoplomyzon cardosoi, MCNG 375, holotype, $18.5 \mathrm{~mm}$ SL. a. Left side in lateral view. b. dorsal view (anterior towards left). ach: anterior ceratohyal; br: branquiostegal rays; vh: ventral hypohyal. Scale bars $=1 \mathrm{~mm}$.

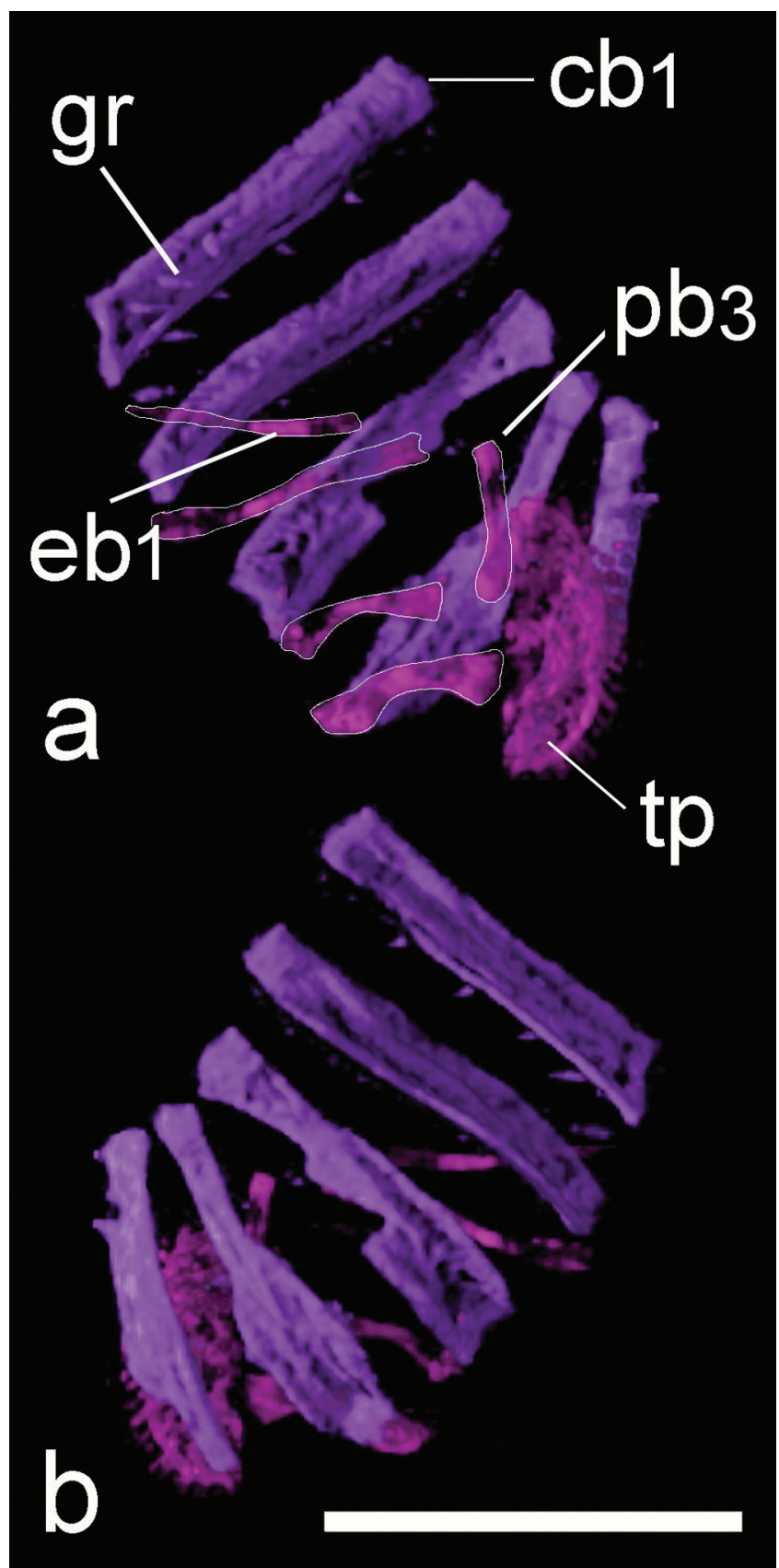

Fig. 7. HRXCT model of left branchial arches of Hoplomyzon cardosoi, MCNG 375, holotype, $18.5 \mathrm{~mm} \mathrm{SL}$. a. Dorsal view (anterior toward top). b. Ventral view. cb1: ceratobranchial 1; eb1: epibranchial 1; pb3: pharyngobranchial 3; tp: tooth plate. Margin of epibranchials and pharyngobranchial 3 highlighted in white. Scale bar $=1 \mathrm{~mm}$.

Sensory canals and associated structures. Nasal present, small and tubular positioned lateral to constricted portion of mesethmoid (Fig. 3a). Infraorbital 1 with anteriorly elongated arm curved medially, dorsal to premaxilla and second medially directed acute process on its dorsal surface. Infraorbital canal entering at medial margin of infraorbital 1 just posterior to medially directed process and exiting from posterior posterolateral surface of bone. 
Remaining infraorbitals reduced to three small, disjointed ossified tubules; infraorbital canal entering anterolateral portion of sphenotic. Sphenotic receiving both infraorbital and supraorbital canals anteriorly. Preopercle-mandibular canal incomplete represented by single short tubular ossification (subpreopercle) anterior to canal entering preopercle; mandibular portion of preopercle-mandibular canal absent. Posterior portion of preopercle-mandibular canal associated with dorsal portion of hyomandibula and entering pterotic posteriorly. Postotic canal exiting from posterior portion of pterotic and entering anterior portion of postemporo-supracleithrum. Pterotic branch and first branch of main lateral line exiting from posteroventral portion of pterotic. Posterior lateral line associated with parapophyses of complex vertebrae of Weberian apparatus, exiting posterolateral portion of that bone and entering posterior lateral-line canal tubules. Posterior lateral line complete reaching hypural region posteriorly. Posterior lateral line canal follow zig-zag course associated with intercalate dorsally and ventrally expanded plate-like structures (lateral plates). Lateral line pores in body, posterior to dorsal-fin origin, associated with elevated posteriorly oriented hookshaped structures of lateral plates (Fig. 3).

Axial skeleton. Dorsal crest of complex vertebrae of Weberian apparatus reaching dorsal surface of body, its dorsal margin strongly concave anteriorly and rising to elevated hump at its posterior tip (Fig. 3). Parapophysis of complex vertebrae short, its posterior end narrowed at contact with parapophyses of vertebra 5 . Ventral portion of complex vertebrae of Weberian apparatus with ventral process forming ring-like arch over aortic canal and additional laterally directed arm; this arm with expanded thin bony blade surrounding gas bladder anteriorly (Fig. 4b). Parapophysis of vertebra 5 long, extending beyond lateral limits of parapophysis of vertebra 4 and reaching body wall. Parapophysis of vertebra 5 directed slightly posteriorly with distal margin not distinctly expanded. Anterior nuchal plate absent. Middle nuchal plate smaller than posterior one, somewhat triangular in shape (dorsal view) and contacting posterior nuchal plate posterolaterally and extensively. Middle nuchal plate distant from dorsal crest of complex vertebrae, ventrally contacting vertebrae 6 and 7. Posterior nuchal plate expanded anterolaterally forming elongate wing with rounded lateral end. Posterior nuchal plate lateral wing posteriorly contacting and overlapping dorsolateral process of vertebra 9 (Fig. 9). Vertebra 9 to last (or penultimate vertebra ventrally) bearing dorso- and ventro-lateral projecting processes, these not overlapping successive ones. Ventrally directed processes of vertebra 9 expanded laterally and bifurcated distally, processes from vertebrae 10 and 11 simple; from 12 and 13 displaced laterally to anal-fin pterygiophore and bifurcated (Fig. 9). Dorsally and ventrally directed vertebral processes bifid next to dorsal and anal fins; fused medially after last vertebrae associated with pterygiophores of those fins. Two entrances for hemal canal; on anteroventral portions of vertebrae 6 and 9. Hemal and neural spines short not elongate except for hemal spines associated with last two vertebrae; hemal spines associated with anal-fin pterygiophores slightly bifid distally. Consecutive vertebrae with interdigitating articulations between their neural and hemal arches. Ribs absent. Hypurals fused; ventral lobe longer than dorsal one, diastema greatly pronounced. Hypurapophysis elongate and greatly expanded laterally to contact lateral plates.

Fins and girdles. Dorsal-fin I,4. Dorsal-fin spinelet absent. First ray simple (not pungent or rigid), slender but thicker than following branched dorsal-fin rays. Last dorsalfin ray adnate to dorsum by membrane. Adipose fin absent.

Anal fin iv,4; last ray not adnate. Caudal fin with 9 principal rays, 5 in dorsal lobe and 4 in ventral lobe; distal margin obliquely truncate, with lower lobe slightly longer than upper lobe. Outermost principal caudal-fin rays unbranched and expanded proximally. Procurrent caudalfin rays small; difficult to visualize in X-ray.

Pectoral fin I,6. First ray spine-like, not pungent; other fin rays branched. Pectoral-fin spine curved with strong deflection inwards at about its midlength (Fig. 8a); conspicuously longer than pectoral-fin branched rays. Anterior margin of pectoral-fin spine smooth; posterior margin with 6 or 7 hooks of similar size except two proximal most ones smaller. Three ossified proximal radials associated with pectoral-fin rays; first radial somewhat triangular in shape; positioned within pectoral-spine proximal cleft; remaining two radials elongate and rod shaped. Dorsal portion of cleithrum with two processes: dorsal process long and narrow with lateral cleft; posterior process articulating to ventral portions of postemporo-supracleithrum and parapophysis of complex vertebrae of Weberian apparatus; posterior process somewhat elongate and triangular, pointed distally (Fig. 8). Cleithrum and scapulocoracoid partly fused, sutures almost indistinguishable. In ventral view, anterior margin of cleithrum transversely straight at and near midline, then deeply concave before prominent joint with pectoral-fin spine (cleithral bulge). Symphysis between cleithrae contacting anteriorly followed by large, circular fenestra on midline, followed posteriorly by heavilyinterdigitating symphyseal suture of scapulocoracoids (Fig. $4 a)$. Cleithrum bearing two small foramina of similar size on its ventral blade: anteromedial one positioned parallel to anterior concavity of cleithrum (Fig. 8: f1) and lateral one positioned near articulation with pectoral-fin spine (Fig. 8: f2). Scapulocoracoid bearing small foramina posterolaterally displaced; positioned lateral to scapulocoracoid posterior process (Fig. 8: f3). Scapulocoracoid bearing short and posteriorly directed process with somewhat squared distal margin.

Pelvic fin i,5; second ray longest, just reaching analfin origin. Lateral and medial anterior processes of basipterygium weakly developed (Fig. 10). Basipterygium with smooth anterior and posterior margins, posteriorly with elongate process. Basipterygium with dorsal process positioned at central portion. 

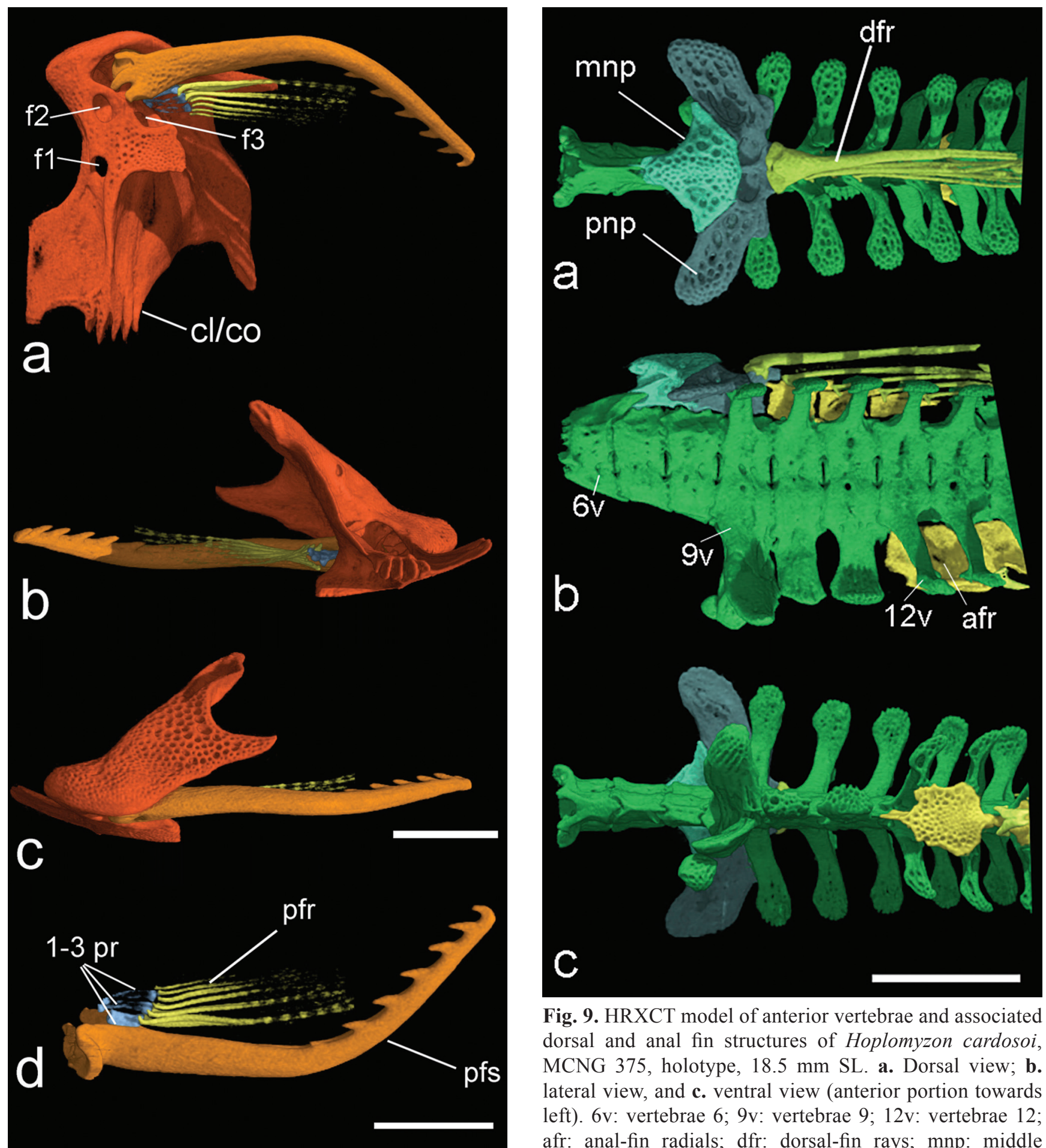

Fig. 8. HRXCT model of left pectoral skeleton of Hoplomyzon cardosoi, MCNG 375, holotype, $18.5 \mathrm{~mm}$ SL. a. ventral view (anterior towards left). b. medial view (anterior towards right). c. lateral view (anterior towards left). d. Dorsal view (anterior towards bottom). 1-3 pr: pectoral-fin proximal radials; cl/co: fused cleithrum-scapulocoracoid; f1: Cleithral arrector dorsalis foramen; f2: Cleithral arrector superficialis foramen; f3: Scapulocoracoidal abdutor superficialis foramen; pfr: pectoral-fin rays; pfs: pectoral-fin spine. Scale bars $=1 \mathrm{~mm}$.

Fig. 9. HRXCT model of anterior vertebrae and associated dorsal and anal fin structures of Hoplomyzon cardosoi, MCNG 375, holotype, $18.5 \mathrm{~mm}$ SL. a. Dorsal view; b. lateral view, and c. ventral view (anterior portion towards left). 6v: vertebrae 6; 9v: vertebrae 9; 12v: vertebrae 12; afr: anal-fin radials; dfr: dorsal-fin rays; mnp: middle nuchal plate; pnp: posterior nuchal plate. Scale bar $=1 \mathrm{~mm}$.

Color in alcohol. Head and body yellowish pale, with scattered brownish chromatophores dispersed mostly on dorsal portions. Dark chromatophores concentrated on internarial and interorbital regions and also on dorsal portion over dorsolateral vertebral processes. All fins hyaline. Pale coloration perhaps due to postmortem bleaching during storage in poor quality alcohol and long exposure to light. 


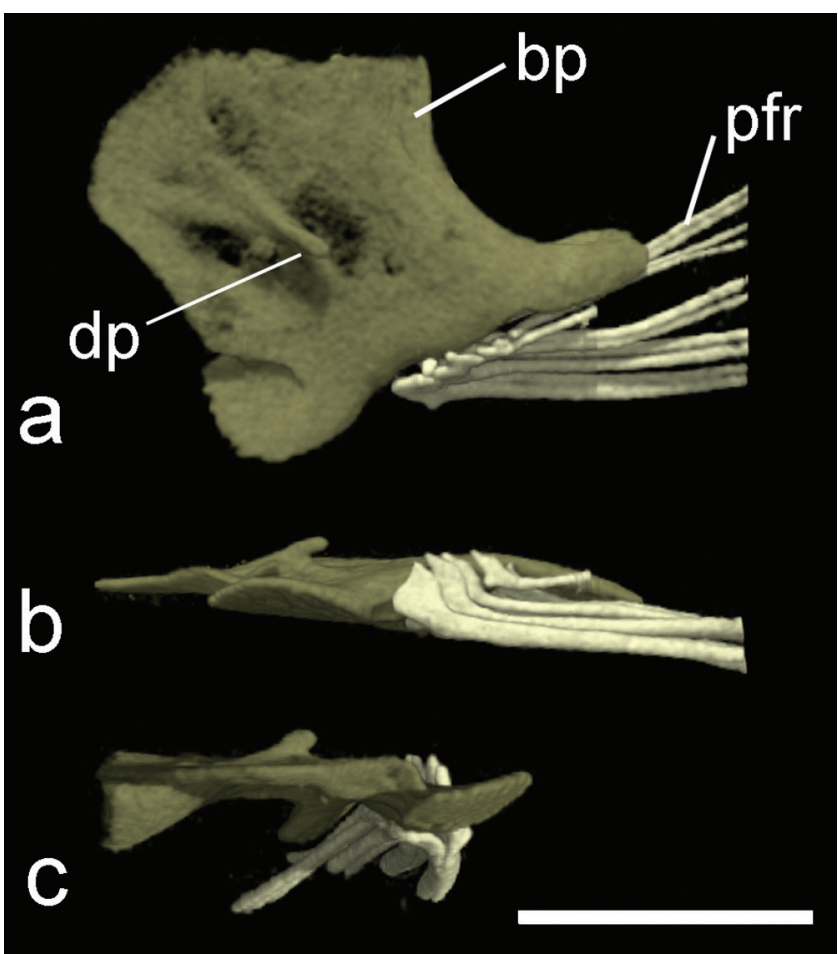

Fig. 10. HRXCT model of pelvic girdle of Hoplomyzon cardosoi, MCNG 375, holotype, $18.5 \mathrm{~mm}$ SL. a. Dorsal view; b. lateral view and c. frontal view. bp: basipterygium; $\mathrm{dp}$ : dorsal process of basipterygium; pfr: pelvic-fin rays. Scale bar $=1 \mathrm{~mm}$.

Distribution and habitat. Known from three tributaries, which drain southwestern portions of Lake Maracaibo Basin in Zulia State, Venezuela (Fig. 12). The Caño raya at type locality is a medium size stream $(\sim 12 \mathrm{~m}$ wide) with mostly slow flowing white waters running over sand intercalated with riffles of fast flowing waters over pebbles; little marginal and floating vegetation.

Etymology. Hoplomyzon cardosoi is named in honor and memory of a dear colleague who prematurely passed away, Alexandre Rodrigues Cardoso, for his humbleness, positive attitude, and dedicated friendship, and furthermore for his contributions to the taxonomy of Neotropical fishes, including the family Aspredinidae.

Conservation status. Hoplomyzon cardosoi is only known from three localities in the southeastern tributaries of the Lake Maracaibo, with an Area of Occupancy (AOO) of 12 square kilometers, estimated considering a $2 \mathrm{~km}$ grid. The Maracaibo Lake has become heavily polluted in the past decades and many mangrove areas have been destroyed or modified by coastal development and land conversion (Reis et al., 2016). The three collecting events occurred from 1977 to 1982 , and intense agriculture developed in the area since then, resulting in continuing decline in habitat quality. Based on the above evidence $H$. cardosoi can be categorized as Near Threatened (NT) by the IUCN criteria (IUCN, 2016).

\section{Discussion}

The new species shares most of the 27 synapomorphies listed for Hoplomyzontini by Friel (1994). The exception is character 24, which, in the derived condition, states that the metapterygoid contacts both the lateral ethmoid anteriorly and the quadrate posteriorly. In Hoplomyzon cardosoi the bony portion of the metapterygoid contacts the lateral ethmoid anteriorly but fails to contact quadrate or hyomandibula posteriorly (Fig. 5), as observed in other Hoplomyzon species. This condition should be taken with caution because variation on the degree of ossification of metapterygoid occurs within individuals of the same species, sometimes bilaterally in the same individual such as that presented by Bunocephalus minerim (Carvalho et $a l ., 2015)$. Characters directly related to cartilage, such as the ascending process of Meckel's cartilage discontinuous with the main portion of that cartilage (ch. 20) and the absence of cartilage on basipterygium anterior to the pelvic-fin rays (ch. 100) were not observed.

Additionally, a new synapomorphy for Hoplomyzontini is proposed, and refers to the pathway of the posterior lateral line associated with the lateral portion of the complex centrum of the Weberian apparatus (Fig. 11). After exiting the posterior portion of the postemporo-supracleithrum the canal enters the parapophysis of the compound centrum, then briefly exit ventrally (Fig. 11a), and finally re-enter bone (Fig. 11b) before exiting posteriorly through an imbricated, ossified lateral-line tubules (Fig. 11c). In other aspredinids the lateral line leaves the postemporosupracleithrum and lies lateral to the parapophyses of the complex centrum of the Weberian apparatus, sometimes passing through laterally displaced ossified canal tubules (Acanthocephalus: Friel, 1995: fig. 2; Pseudobunocephalus: Friel, 2008: fig. 3; Bunocephalus: Carvalho et al., 2015: fig. 3; Amaralia: Friel, Carvalho, 2016: fig. 4; Xyliphius: Carvalho et al., in press: fig. 9c). This unique condition was clearly observed and described with the aid of computed microtomography reconstructions, but also assessed and evaluated within other Hoplomyzontini based on cleared and stained specimens (see comparative material).

Hoplomyzon cardosoi shares, in part, with other putative congeners an apomorphic feature proposed by Friel (1994: ch. 13; Tab. 2.) in which the ventral surface of the premaxilla has two bony knobs presumably associated with external fleshy papillae. The new species has the papillae on the ventral surface of upper jaw, a condition similar to other Hoplomyzon species, but lack the bony knobs on the ventral surface of premaxilla (Fig. 4a). Therefore the external fleshy papillae and the bony knobs on the ventral margin of premaxilla have likely independent origins, the former being more inclusive to all Hoplomyzon, and the latter appearing in a less inclusive clade containing all other species of Hoplomyzon except $H$. cardosoi. The bony knobs are located on the posterolateral and medial portions of the premaxilla, the lateral one being 
larger and associated with few and small acicular teeth in $H$. papillatus. In $H$. sexpapilostoma, the medial bony knob is larger than the posterolateral one and both knobs lack teeth, perhaps because these feebly attached teeth were lost during preservation and/or clearing and staining.

Other diagnostic features of Hoplomyzon according to Friel (1994) are: 1) the dorsal and ventral vertebral lateral processes not overlapping adjacent ones, 2) two or three sets of paired ventral vertebral processes anterior to anal-fin pterygiophores, 3) maxillary barbel adnate to head by membrane, and 4) pectoral-fin spine short (less than 25\% SL). Hoplomyzon cardosoi shares with other species of Hoplomyzon vertebral processes not overlapping adjacent ones (Figs. 3, 4 and 9), contrasting with adjacent processes overlapping subsequent ones in other species of Hoplomyzontini (Friel, 1994; Friel, Lundberg, 1996: fig. 4a). This feature has an ambiguous optimization if Hoplomyzon is the sister group to remaining Hoplomyzontini (Friel, 1994; Friel, Lundberg, 1996). Outgroup aspredinids lack comparable vertebral processes. Regarding the configuration of the ventral vertebral processes anterior to anal fin within Hoplomyzontini, the new species differs from other Hoplomyzon (Tab. 2.), and other Hoplomyzontini, by having a single paired process associated with the vertebra $8(n=1, M C N G$ 26955) or vertebrae $9(\mathrm{n}=2)$ and two single processes anterior to anal-fin pterygiophore on vertebrae 10 and 11 (Figs. 9b-c). However, the new species shares with other Hoplomyzon the relative posterior position of the anal-fin, in which its pterygiophore is situated between the vertebrae 12 and 13, contrasting with an anal-fin pterygiophore situated between the vertebrae 11 and 12 in remaining Hoplomyzontini (Friel, Lundberg, 1996), another feature of ambiguous optimization due to inadequate comparisons of this structure with outgroups. Maxillary barbels are to some degree adnate to the head by a membrane in all Hoplomyzontini genera and do not diagnose Hoplomyzon from remaining taxa within the tribe. Regarding the length of the pectoral-fin spine; the relatively short pectoral spine is likely a plesiomorphic feature within Hoplomyzontini (Friel, Lundberg, 1996).

An additional putative synapomorphy for Hoplomyzon, although not confirmed in $H$. atrizona, is the absence of an uncinate process on epibranchial 3 (Fig. 7). The third epibranchial bears an uncinate process in all aspredinids except the genus Pseudobunocephalus. Since both genera are not closely related (Friel, 1994), this is likely an independent loss.

An interesting apomorphic feature in Hoplomyzon cardoso $i$ is the presence of elongated mental filaments on the ventral surface of head and cleithrum. A similar condition is found in Ernstichthys intonsus (Stewart, 1985: fig. 3), and to some degree small papillary structures are found in the same region in other members of the Hoplomyzontini (Stewart, 1985: fig. 2b; Taphorn, Marrero, 1990: fig. 1d). Such structures are shorter in these other hoplomyzontins representatives, but seem homologous to the additional mental filaments that are hypertrophied in adults of $H$. cardosoi and presumably Ernstichthys intonsus. The presence of these mental filaments in Aspredinidae is not unique for hoplomyzontins, as they are also found in the genus Aspredinichthys (Mees, 1987: figs. 1-2).

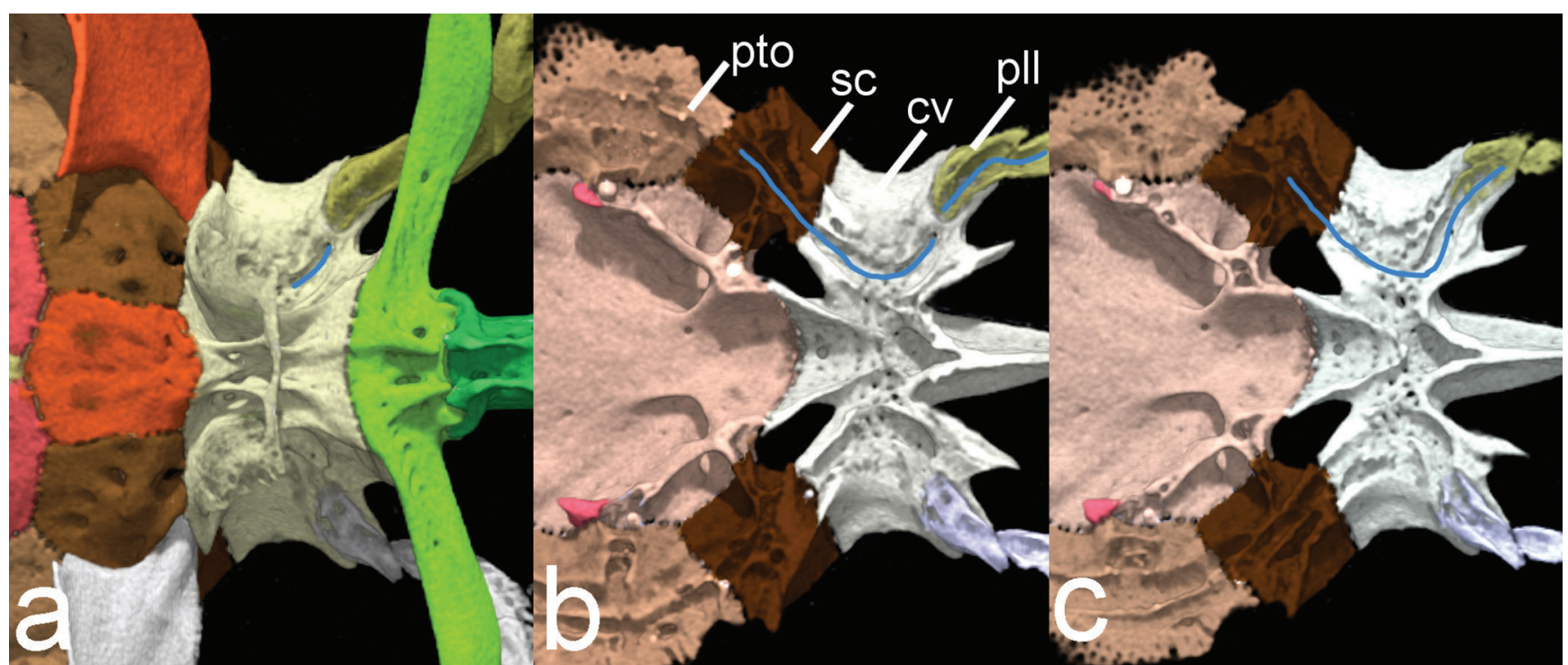

Fig. 11. Sequential cut of complex vertebrae of Weberian apparatus and elements associated with posterior lateral line in ventral view of Hoplomyzon cardosoi, MCNG 375, holotype, $18.5 \mathrm{~mm} \mathrm{SL}$. a. Ventral view, b. cut at horizontal line at about dorsal limit of vertebra 5, and c. cut at horizontal line at about dorsal limit of second posterior lateral line tubule. Left side of posterior lateral line canal pathway highlighted in blue. cv: complex vertebrae; pll: posterior lateral line tubule; pto: pterotic; sc: postemporo-supracleithrum. 
Tab. 2. Summary of characteristics variable within Hoplomyzon species based on examined material and literature (Stewart, 1985; Taphorn, Marrero 1990).

\begin{tabular}{|c|c|c|c|c|}
\hline Character/species & Hoplomyzon atrizona & Hoplomyzon cardosoi & Hoplomyzon papillatus & Hoplomyzon sexpapilostoma \\
\hline $\begin{array}{l}\text { Shape of anterior margin of } \\
\text { mesethmoid }\end{array}$ & $\begin{array}{l}\text { Median furrow and undeveloped } \\
\text { cornua }\end{array}$ & $\begin{array}{l}\text { Straight and slightly } \\
\text { developed cornua }\end{array}$ & $\begin{array}{l}\text { Deep median furrow and } \\
\text { developed cornua }\end{array}$ & $\begin{array}{l}\text { Deep median furrow and } \\
\text { developed cornua }\end{array}$ \\
\hline Ventral surface of premaxilla & With paired bony knobs & Smooth & With paired bony knobs & With paired bony knobs \\
\hline Premaxillary teeth & Not examined & Absent & Present & Present \\
\hline Dentary teeth & Present & Absent & Present & Present \\
\hline Upper lip symphyseal papilla & Paired & Unpaired & Unpaired & Paired \\
\hline Rictal barbel & Well developed & Well developed & Short & Short \\
\hline Dorsal-fin rays & Seven & Five & Five & Six \\
\hline Anal-fin rays & Six & Eight & Six & Seven \\
\hline $\begin{array}{l}\text { Vertebrae and shape of ventral } \\
\text { pre-anal fin processes. }\end{array}$ & $\begin{array}{l}\text { 8-9 laterally expanded; } 10-11 \\
\text { branched }\end{array}$ & $\begin{array}{l}9 \text { laterally expanded } \\
10-11 \text { simple }\end{array}$ & $\begin{array}{l}\text { 8-9 laterally expanded; } \\
10-11 \text { branched }\end{array}$ & $\begin{array}{l}\text { 9-10 laterally expanded; } 11 \\
\text { branched; }\end{array}$ \\
\hline Number of vertebrae & $30-31(\mathrm{n}=2)$ & $30-32(\mathrm{n}=3)$ & $29-30(\mathrm{n}=2)$ & $29(\mathrm{n}=1)$ \\
\hline Posterior lateral line & $\begin{array}{l}\text { Somewhat straight on anterior } \\
\text { body }\end{array}$ & Zig-zag on anterior body & Zig-zag on anterior body & $\begin{array}{l}\text { Somewhat straight on } \\
\text { anterior body }\end{array}$ \\
\hline
\end{tabular}

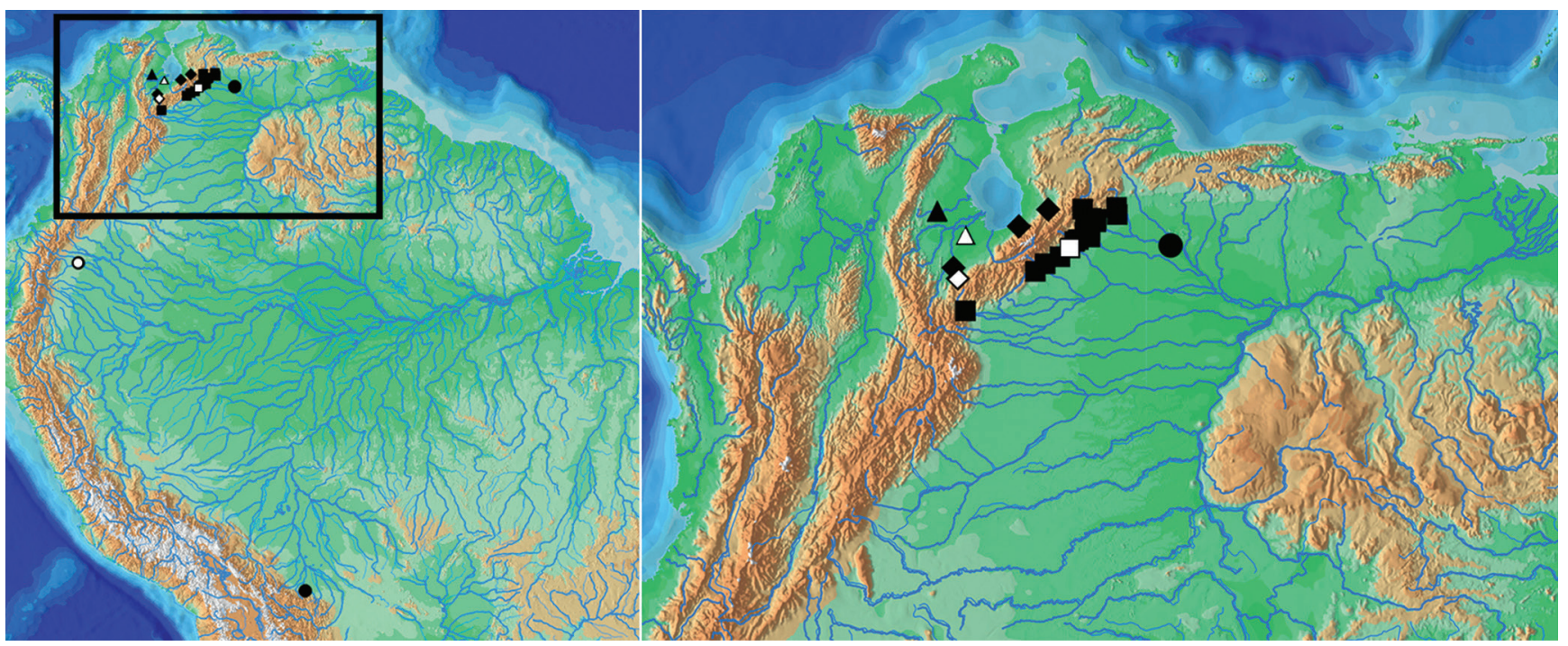

Fig. 12. Distributions of species of Hoplomyzon based on examined museum specimens and literature records (Stewart, 1985; Taphorn, Marrero, 1990). Triangles: H. cardosoi; diamonds: H. atrizona; circles: H. papillatus and squares: H. sexpapilostoma. White symbols represent respective type localities. One symbol may represent more than one locality.

Hoplomyzon cardosoi is small with a mature female measuring $18.5 \mathrm{~mm} \mathrm{SL}$, and can be categorized as miniature (Weitzman, Vari, 1988). In Aspredinidae, miniaturization occurs not only in Hoplomyzontini (e.g., H. cardosoi, H. papillatus, Micromyzon akamai, and M. orinoco) but also in an unrelated species (e.g., Acanthobunocephalus nicoi), implying that extreme size reduction has occurred independently multiple times within the evolution of the family. Microtomography reconstruction proved to be an optimal tool for the detailed study of osteological features in miniature fish that have well calcified skeletons, such as the hoplomyzontins.

The high degree of endemism of fishes from the Maracaibo Basin is an aspect reflecting mostly the isolation of this region since the rise of the Cordillera Merida in the late Miocene (Albert et al., 2006; Hardman, Lundberg, 2006). An interesting aspect of Lake Maracaibo Basin is the apparent allopatric distribution in this region of $H$. cardosoi and its congener $H$. atrizona, the former being found in southwestern and lower portions and the latter in south-southeastern and upper portions of the basin. Lake Maracaibo Basin, together with the Orinoco River basin, are the regions with the highest diversity of hoplomyzontins with three (H. atrizona, H. cardosoi, and Dupoyichthys sapito) and four species (H. sexpapilostoma, H. papillatus, Ernsticthys anduzei, and Micromyzon orinoco) respectively, representing the center of diversity of hoplomyzontins in South American drainages. 
Comparative material examined. In addition to the material listed in previous publications (Carvalho et al., 2015, 2016; and Friel, Carvalho, 2016), the following lots were examined: Hoplomyzon atrizona: Venezuela. UF 30762, 1. MCNG 24796, $4+1$ cs. Bolivia. USNM 121070, holotype of Hoplomyzon atrizona petroleus. USNM 121071, 1 paratype of Hoplomyzon atrizona petroleus. USNM 130639, 1 paratype of Hoplomyzon atrizona. Hoplomyzon papillatus: Bolivia: UMSS 15701, 3. Ecuador: FMNH 94908, holotype. Venezuela: MCNG 24228, 1. Hoplomyzon sexpapilostoma: Venezuela: ANSP 164977, 1cs. UF 47525, 5 paratypes. CUMV 78528, 1. CUMV 78542, 1. CUMV 78603, 1. CUMV 78629, 1. CUMV 78737, 1. CUMV 79746, 1. CUMV 82559, 1. CUMV 90168, 8. FMNH 97762, 5 paratypes. USNM 194160, 2.

\section{Acknowledgments}

We are grateful to the following people for loan of specimens and hospitality while visiting museums: M. Sabaj, K. Luckenbill, and J. Lundberg (ANSP), C. MacMahan, S. Mochel, and K. Swagel (FMNH), C. Oliveira and F. Roxo (LBP), D. Taphorn and O. Castillo (MCNG), C. Lucena and M. Lucena (MCP), S. FischMüller and R. Covain (MHNG), M. de Pinna, A. Datovo and O. Oyakawa (MZUSP); C. Dardia (CUMV), R. Robins (UF); L. Malabarba and J. Wingert (UFRGS); F. Carvajal (UMSS); R. Vari and S. Raredon (USNM). We deeply acknowledge D. Taphorn for bringing specimens of this new species to our attention and for information on type locality. We thank J. Maisano and M. Colbert (UT Austin) for preparation of computed tomography x-rays and K. Luckenbill (ANSP) for help in image editing with VGStudio Max software. This research was partially supported by Conselho Nacional de Desenvolvimento Científico e Tecnológico (CNPq) (process number 229355/2013-7 to TPC, and processes number 305180/2010-0 and 207038/2013-9 to RER), and Fundação de Amparo à Pesquisa do Estado do Rio Grande do Sul - FAPERGS (process number 2361-2551/147 to RER). First author is currently supported with a postdoctoral scholarship PNPD-CAPES. Thanks to A. Londoño-Burbano for translating the abstract to Spanish. We also thank John Lundberg for discussions on catfish morphology and review of the manuscript previous to submission.

\section{References}

Albert JS, Lovejoy NR, Crampton WGR. Miocene tectonism and the separation of cis- and trans-Andean river drainages: Evidence from Neotropical fishes. J South Am Earth Sci. 2006; 21(1):14-27.

Albert JS, Petry P, Reis RE. Major biogeographic and phylogenetic patterns. In: Albert JS, Reis RE, editors. Historical biogeography of Neotropical freshwater fishes. Berkeley: UCPress; 2011. p.21-57.
Cardoso AR. Filogenia da família Aspredinidae Adams, 1854 e revisão taxonômica de Bunocephalinae Eigenmann \& Eigenmann, 1888 (Teleostei: Siluriformes: Aspredinidae). [PhD Thesis]. Porto Alegre, RS: Pontifícia Universidade Católica do Rio Grande do Sul; 2008.

Cardoso AR. Bunocephalus erondinae, a new species of banjo catfish from southern Brazil (Siluriformes: Aspredinidae). Neotrop Ichthyol. 2010; 8(3):607-13.

Carvalho TP, Cardoso AR, Friel JP, Reis RE. Two new species of the banjo catfish Bunocephalus Kner (Siluriformes: Aspredinidae) from the upper and middle rio São Francisco basins, Brazil. Neotrop Ichthyol. 2015; 13(3):499-512.

Carvalho TP, Lundberg JG, Baskin JN, Friel JP, Reis RE. A new species of the blind and miniature genus Micromyzon Friel and Lundberg, 1996 (Silurifomes: Aspredinidae) from the Orinoco river: describing catfish diversity using high-resolution computed tomography. Proc. Acad. Nat. Sci. Philadelphia. 2016; 165(1):37-53.

Carvalho TP, Reis RE, Sabaj MH. Description of a new blind and rare species of Xyliphius (Silurifomes: Aspredinidae) from the Amazon basin using high-resolution computed tomography. Copeia. Forthcoming 2017.

Dahdul WM, Lundberg JG, Midford PE, Balhoff JP, Lapp H, Vision TJ, Haendel MA, Westerfield M, Mabee PM. The teleost anatomy ontology: anatomical representation for the genomics age. Syst Biol. 2010; 59(4):369-83.

Friel JP. A phylogenetic study of the Neotropical banjo catfishes (Teleostei: Siluriformes: Aspredinidae). [PhD Thesis]. Durham, NC: Duke University; 1994.

Friel JP. Acanthobunocephalus nicoi a new genus and species of miniature banjo catfishes from the upper Orinoco and Casiquiare rivers, Venezuela (Siluriformes: Aspredinidae). Ichthyol Explor Freshw. 1995; 6(1):89-95.

Friel JP. Family Aspredinidae. In: Reis RE, Kullander SO, Ferraris CJ, Jr., organizers. Check list of the freshwater fishes of South and Central America. Porto Alegre: Edipucrs; 2003. p.261-267.

Friel JP. Pseudobunocephalus, a new genus of banjo catfish with the description of a new species from Orinoco river system of Colombia and Venezuela (Siluriformes: Aspredinidae). Neotrop Ichthyol. 2008; 6(3):293-300.

Friel JP, Carvalho TP. A new species of Amaralia Fowler (Siluriformes: Aspredinidae) from the Paraná-Paraguay river basin. Zootaxa. 2016; 4088(4):531-46.

Friel JP, Lundberg JG. Micromyzon akamai, gen. et spec. nov., a small and eyeless banjo catfish (Siluriformes: Aspredinidae) from the river channels of the lower Amazon basin. Copeia. 1996(3):641-48.

Hardman M, Lundberg JG. Molecular phylogeny and a chronology of diversification for "phractocephaline" catfishes (Siluriformes: Pimelodidae) based on mitochondrial DNA and nuclear recombination activating gene 2 sequences. Mol Phylogenet Evol. 2006; 40(2):410-18.

International Union for Conservation of Nature (IUCN). Standards and Petitions Subcommittee. Guidelines for using the IUCN Red List Categories and Criteria. Version 12 [Internet]. 2016 [updated 2016 Feb]. Available from: http://cmsdocs. s3.amazonaws.com/RedListGuidelines.pdf 
Lundberg JG, Baskin JN. The caudal skeleton of the catfishes, Order Siluriformes. New York: American Museum of Natural History; 1969. (American Museum Novitates; No. 2398).

Mees GF. The members of the subfamily Aspredininae, family Aspredinidae in Surinam (Pisces, Nematognathi). Proc Kon Ned Akad Wetensch, Ser C, Biol Med Sci. 1987; 90(2):173-92.

Mungall CJ, Torniai C, Gkoutos GV, Lewis SE, Haendel MA. Uberon, an integrative multi-species anatomy ontology. Genome Biol. 2012; 13(1): R5[20p.].

de Pinna MCC. A phylogenetic analysis of the Asian catfish families Sisoridae, Akysidae, and Amblypidae, with hypothesis on the relationships of the Neotropical Aspredinidae (Teleostei, Ostariophysi). Chicago: Field Museum of Natural History; 1996. (Fieldiana, Zoology, New series; No. 84).

de Pinna MCC, Ng HH. The second ural centrum in Siluriformes and its implication for the monophyly of superfamily Sisoroidea (Teleostei, Ostariophysi). New York: American Museum of Natural History; 2004. (American Museum Novitates; No. 3437).

Reis RE, Albert JS, Di Dario F, Mincarone MM, Petry P, Rocha LA. Fish biodiversity and conservation in South America. J Fish Biol. 2016; 89(1):12-47.

Sabaj MH. American Society of Ichthyologists and Herpetologists. Standard symbolic codes for institutional resource collections in herpetology and ichthyology: an online reference. Version 6.5 [Internet]. 2016. [updated 2016 August 16] Available from: http://www.asih.org/sites/default/files/documents/symbolic codes_for_collections_v6.5.pdf
Sabaj Pérez MH. Photographic atlas of fishes of Guiana Shield. Bull Biol SocWash. 2009; 17(1):53-9.

Stewart DJ. A review of the South American catfish tribe Hoplomyzontini (Pisces, Aspredinidae), with descriptions of new species from Ecuador. Chicago: Field Museum of Natural History; 1985. (Fieldiana, Zoology, New series; No. 25).

Taphorn DC, Marrero C. Hoplomyzon sexpapilostoma, a new species of Venezuelan catfish (Pisces: Aspredinidae), with comments on the Hoplomyzontini. Chicago: Field Museum of Natural History; 1990. (Fieldiana, Zoolology, New series; No. 61).

Taylor WR, Van Dyke GC. Revised procedures for staining and clearing small fishes and other vertebrates for bone and cartilage. Cybium. 1985; 9(2):107-19.

Weitzman SH, Vari RP. 1988. Miniaturization in South American freshwater fishes; overview and discussion. Proc Biol Soc Wash. 1988; 101(2):444-65. 